\title{
Review: Using Jail for Child Support Enforcement
}

\author{
Robert H. Mnookin $\dagger$
}

A few years after a divorce, most fathers ${ }^{1}$ are not paying child support. Although their legal obligation to pay usually is clear-a court in a divorce proceeding typically orders the father to pay a specific amount-many do not pay. Because most states provide no effective mechanism for enforcing child support obligations, nonpaying fathers usually get away with it.

This state of affairs has been known for some time. In the mid-1960s, for example, Kenneth Eckhardt followed child support payments of 163 divorced men in Dane County, Wisconsin over the ten-year period following their divorces. He discovered that by the seventh year after divorce, $\mathbf{7 1 \%}$ of the fathers made no payments and only $17 \%$ made full payments. ${ }^{2}$ Reliable national data are scarce, but one study based on a 1975 sample found that over $60 \%$ of absent fathers paid nothing toward support of their children. ${ }^{3}$ Overall, divorced fathers as a group probably pay only about a third of what courts have ordered them to pay. 4 Because the proportion of children who now spend some part of their youth with a single parent has increased rapidly during the past two decades, these facts suggest a policy problem of considerable dimension.

The failure of many absent fathers to pay support has important consequences for children, custodial parents, and society at

$\dagger$ Visiting Professor of Law, Stanford Law School. I gratefully acknowledge the help of my research assistant, Susan Termohlen, Stanford Law School class of 1981 .

${ }^{1}$ Historically, the support obligations of fathers and mothers differed, but many states now make the mother and father equally responsible for support of their children. See $\mathrm{R}$. MNookin, Child, Family and State 175 (1977). Nevertheless, although mothers sometimes are ordered to pay child support to custodial fathers, the use in this review of "father" as the noncustodial, support-paying parent reflects the predominant reality.

2 K. Eckhardt, Social Change, Legal Controls, and Child Support: A Study in the Sociology of Law (1965) (Ph.D. thesis, Sociology, University of Wisconsin), summarized in Eckhardt, Deviance, Visibility, and Legal Action: The Duty to Support, 15 Soc. Proв. 470 (1968).

${ }^{3}$ See J. Cassetty, Chind Support and Public Policy 65 (1978). These figures include fathers who were not under court orders to pay support.

4 See Baldus, Book Review, 78 Mrch. L. Rev. 750, 750 (1980).

s See M. Bane, Here to Stay 12-14 (1976). 
large. Child support is an important source of maintenance, although even full payment is not enough by itself to sustain most single-parent households. Failure to pay reduces the income available for the child's welfare, thereby increasing the pressure on the single parent to augment her income through employment, remarriage, or welfare assistance. ${ }^{\circ}$ Because Aid to Families with Dependent Children ("AFDC") eligibility and benefits take into account support payments actually made by the absent parent, the private support obligation and public welfare programs are inextricably tied together. Congress has recognized the obvious implication: the failure of fathers to pay child support increases the number of women requiring welfare, as well as the costs of AFDC for those who would be eligible even if the father paid. ${ }^{8}$

Of course, one can challenge the underlying assumption that noncustodial parents should be economically responsible for child support. Because large numbers of otherwise law-abiding men will not make support payments voluntarily, it might be thought that the legal requirement should be changed to reflect the social pattern. Anyone who wishes to argue that fathers should not be compelled to pay, however, must suggest who, if not the father, should bear the costs. Should the burden be on the child and the custodial mother? Or should it be on the state? The evidence suggests that most single-parent households are considerably less well off economically than the father's household, at least until the mother remarries. ${ }^{\circ}$ Furthermore, many would question the appropriateness of public support when a father has sufficient resources.

If one decides that absent parents should share the financial burden, the obvious question is how to make them pay. What works? What is fair? Are some states or communities more effective in their collection efforts than others, and if so, why? In Making Fathers Pay, David Chambers contributes much to our understanding of these important issues.

- See D. Chambers, Making Fathers Pay 67 (1979) [hereinafter cited without crossreference as Chambers].

72 U.S.C. $\$ \S 602(a)(7)(1976)$.

- In 1975, Congress enacted amendments to the Social Security Act that broadly expanded the role of the federal government in child support enforcement. The legislation requires states, as a condition for receiving matching funds through the AFDC program, to formulate and implement plans for enforcing support obligations. The states and the federal government must cooperate to establish procedures for locating absent parents, for establishing paternity of children born out of wedlock, and for enforcing support obligations. See id. $\S \S 651-660$; R. MNookIn, supra note 1, at 248.

- See J. CASSETTY, supra note 3, at 68; Chambers at 45-48, 63-66. 
Chambers's book is based in part on original empirical research concerning Michigan's unique system for enforcing child support. Each county in Michigan has an administrative body, known as the Friend of the Court, that runs a collection agency for enforcing support orders. This agency is responsible for investigating nonpayment, for issuing warnings, and for initiating formal legal proceedings to make fathers pay. ${ }^{10}$ Furthermore, Michigan fathers typically make their support payments not directly to the mother but rather to the Friend of the Court, which remits the money to the mother. ${ }^{11}$

Chambers's decision to study Michigan's system was a felicitous one for three reasons. First, the Friends of the Court are remarkably effective-Michigan collects far more child support than any other state. ${ }^{12}$ Second, the records of the Friends of the Court contain a wealth of information about the payment patterns of absent fathers. Third, because the enforcement techniques used by various Friends of the Court differ, ${ }^{13}$ Chambers had an opportunity to compare the performance of Michigan's counties and to investigate the enforcement factors that appear to work and those that do not.

The primary concern of Chambers's book is the use of jail as the ultimate sanction for compelling divorced fathers to pay child support. In addition to enforcing support through garnishment or attachment, courts in most states have the equitable power to hold in contempt a father who refuses to pay, and to send him to jail until he pays or agrees to pay. ${ }^{14}$

10 Chambers at 10-13. These services extend to both welfare and nonwelfare cases. A Friend of the Court has other duties as well, such as overseeing all official matters relating to divorce and paternity, and advising the court on custody, visitation, and the size of support orders. Id.

11 Id.

${ }^{12}$ In 1978, for example, Michigan's collections on behalf of families receiving AFDC amounted to more than any other state's, and far more than the combined total collected by New York, Illinois, and Pennsylvania. Office of Child Support Enporcement, HEW, Child SUPPORT ENFORCEMENT 91 (1978). Its record for non-AFDC collections is even more impressive. In 1978 Michigan collected nearly a quarter of the amount that all states combined collected. Id. at 97 .

1s See Chambers at 12-13, 17-18.

14 See, e.g., Mich. Comp. LAws ANN. § 552.201 (1967). Michigan permits incarceration of a defendant for contempt where "by the exercise of diligence [he] could be of sufficient ability" to pay. Id. From Chambers's description, it appears that some Michigan courts may have held men in civil contempt upon a showing that they willfully failed in the past to comply with the support order, without any inquiry into whether they could comply at present and if so to what extent. CHAMBERS at 175-77. A father's present inability to comply is a complete defense in some states, but it appears that Michigan law was (and perhaps is) less 
Chambers's central empirical finding was that the use of jail leads to considerably higher support payments if a county also has a well-organized, self-starting enforcement system, one that does not wait until a mother complains to initiate collection. ${ }^{15} \mathrm{He}$ also found that it is the frequency with which jail is used and not the length of a jail term that is significant. ${ }^{16}$ In addition, although he found differences in payment patterns for various groups of fathers, in general the credible threat of jail in a well-organized county appears to raise the payment rates for every group. ${ }^{17} \mathrm{Fi}$ nally, in addition to evidence of general deterrence, Chambers found evidence of specific deterrence-many fathers who went to jail thereafter paid more. ${ }^{18}$

From the unconventional structure of the book, it appears that these findings were not the answers Chambers was seeking when he embarked on his project in 1971. The book essentially weaves together three separate strands. One strand laces throughout the book the results of his formal empirical research, findings that show a relationship between jailing and higher support payments. Another is the story of one father-"Jerry Neal"10 - who was sent to jail for failing to make support payments. This infor$\mathrm{mal}$, anecdotal, and somewhat unrepresentative ${ }^{20}$ case history per-

strict in this regard. Chambers asserts that in Genesee County in 1969-70, "[j]udges never inquired whether men had cash on hand equal to the portion of the arrearage demanded as the price of release." Id. at 187. In 1976 the Michigan Supreme Court did make clear, however, that a trial judge must make a determination of a man's "present ability to pay," which requires more than a simple finding of physical ability to work. Sword v. Sword, 399 Mich. $367,379,249$ N.W.2d 88, 92 (1976). Sword suggests that a trial court must find at the time the man is sentenced to jail that he has sufficient ability or by the exercise of due diligence could be of sufficient ability to comply with the court's order to pay at least some money. Although it seems that Michigan law requires that the amount ordered as a condition of release be within the man's present financial ability, how a court is to determine the amount is problematic. See text at note 121 infra. One Michigan court has held that it is proper to find present ability to comply even when a father is unemployed, if he makes no explanation of the efforts he has made to get a job. In Butler v. Butler, 80 Mich. App. 696, 265 N.W.2d 17 (1978), the court held that it was not an abuse of discretion to send to jail an unemployed arthritic man ordered to pay $\$ 300$ when, about a month after suspending the sentence with an admonishment for the man to find employment, the defendant at the subsequent hearing stated only that he was still unemployed and arthritic and did not recite what measures he had taken to find suitable employment.

${ }^{16}$ Chambers at 90-91. For my discussion of this variable, see note 95 infra.

16 Chambers at 95. See note 70 infra.

17 Chambers at 90-101. See text and note at note 53 infra.

18 Chambers at 101. See text and notes at notes 70-75 infra.

10 Chambers gives the man a fictitious name and changes several details in the lives of his family. CHambers at $4 \mathrm{n} .^{*}$

${ }^{20} \mathrm{Neal}$ was atypical in that his former wife was on welfare, $i d$. at 59 ; he was repeatedly 
mits Chambers to expose the human dimension of support enforcement and to reveal his own ambivalent feelings of anger and pity about this man and his failure to pay. Because it is unclear whether jailing was useful for Jerry Neal, ${ }^{21}$ this story serves as a counterpoint for the statistical research and presages Chambers's own dissatisfaction with jailing for nonsupport. The third strand-and for Chambers perhaps the most important-is an argument against the use of jail in enforcing the support obligations of fathers.

This structure highlights the evident tension between Chambers's formal empirical findings-that jail is an effective sanction-and his own deeply felt notions of fairness. He believes that jails are inhumane and that it is unfair to send men to them for the failure to pay support. Chambers writes beautifully, and the passion that informs his views is evident throughout the book. $\mathrm{He}$ is an able advocate, committed to arguing the case against jail; as he recognizes, however, his argument is weakened by his own empirical findings. The book is important and impressive in many ways, yet the underlying tension is not resolved in a way that I found entirely satisfactory.

Chambers's empirical research would have been more useful had he developed and tested a coherent theory against his data and related his study more fully to prior theoretical and empirical research. Also, I wish he had presented his methods and findings in a way that more closely followed social science conventions. The research is described in a manner that makes it unnecessarily difficult to evaluate. Another problem is that although he discloses his values with candor, his analysis and description sometimes are heavily colored by those values, and presented in too personal and informal a way.

Similar difficulties extend to Chambers's argument against jail. His argument rests in important measure not simply upon his values, but also upon a range of empirical assumptions, some of which are unrelated to his formal empirical analysis. It is often difficult to distinguish these untested empirical assumptions and understand just what Chambers's own data show. Most fundamentally, I find his arguments against jail unpersuasive.

jailed, $i d$. at 198; he was married three times, $i d$. at 281; and apparently he was unwilling to pay any child support to buy his way out of jail, id. at 198-99.

${ }^{21}$ Neal was jailed three times, but when the book ends it is uncertain whether at last he will maintain his support payments. See id. at 282. 
This review first will summarize Chambers's empirical analysis and his methodology. Then it will suggest why a general approach that placed greater emphasis on developing and testing a theory would have been preferable, and will briefly describe a simple deterrence theory that seems consistent with Chambers's results. Finally, it will analyze Chambers's arguments against the use of jail and explain why they are unpersuasive.

Reduced to its essential terms, Chambers's empirical analysis concerns two issues. The first is why some Michigan counties collect much more child support than other counties in that state. $\mathrm{He}$ devotes particular attention to whether the frequent use of jail as a sanction against fathers who are delinquent in making child support payments leads to greater collections. The second issue concerns which types of fathers pay more and which pay less, and how different classes of fathers respond to different enforcement methods. Chambers was concerned especially with which men were jailed and with their payment patterns after their release.

He investigated the first issue primarily by analyzing the differences in collection rates for twenty-eight Michigan counties. ${ }^{22}$ For each county he used a sample of outstanding support orders to estimate an average collection rate. There was considerable variation in the overall collection rates among the counties. The worst county, Wayne, collected about $45 \%$ of the amount that fathers owed, while the best county, Barry, collected about $87 \% .^{23}$

Using regression analysis, ${ }^{24}$ Chambers next attempted to explain the differences in county collection rates. For these purposes, he developed explanatory variables from three types of information. First, from existing sources, primarily the 1970 census, he compiled data about each county's population, ethnic composition, average educational levels, labor force participation rates, income levels, and rates of employment. ${ }^{2 s}$ Second, from information he

22 Chambers originally had set out to study all of the 30 Michigan counties with more than 1,000 active support orders in 1973. Two counties were dropped because data collection times could not be arranged. Id. at 297-98.

23 Id. at 97.

24 The techniques Chambers uses in his analysis are summarized in a methodological appendix, id. at 283-303, and his use of regression analysis is explained in a note, $i d$. at 60 n.18.

${ }^{23}$ Id. at $297-98$. 
gathered, he developed a jailing rate for each county. ${ }^{26}$ The rates varied considerably, the highest-jailing counties using jail ten times more often, proportional to the caseload, than the lowest. ${ }^{27}$ Third, he obtained information about the operation of the Friends of the Court in each of the twenty-eight counties. This included data about the caseload size in each county, the size and credentials of the staff, and the various enforcement techniques typically used. ${ }^{28}$

After testing some forty variables, Chambers found that three factors stood out as "powerfully related" to the variations of collections among the counties. ${ }^{29}$ One was whether the enforcement system in a county was self-starting, that is, whether it had a policy of initiating enforcement efforts in nonwelfare cases without waiting for complaints from the mother about nonpayment. ${ }^{30}$ The second was the jailing rate. "After controlling for other factors, we found that counties that jailed more men collected at higher rates-if, but only if, they also had self-starting enforcement systems."31 The third was population. ${ }^{32}$ The smaller counties consistently collected at higher rates than the larger counties. None of the seven highestcollecting counties had populations above 70,000, while nine of the ten lowest-collecting counties had populations greater than $110,000 .^{33}$

Chambers found that the effects of the self-starting variable and the jailing rate were linked. "A county had to have both a selfstarting enforcement system and a substantial rate of jailing in order to add appreciably to collections." $34 \mathrm{He}$ repeatedly emphasizes that "[c]ounties with a high jail rate but no self-starting system of

${ }^{26}$ Chambers considered the number of jail sentences for contempt of court for nonpayment for each 10,000 persons in the county. Id. at 321 . Because the caseload size and county populations were highly correlated, this rate was roughly equivalent to the number of jailings per 250 in the caseload. Id. at $84 \mathrm{n} .4$. For my discussion of the jailing-rate variable, see note 94 infra.

27 Chambers at 84.

${ }^{28}$ Id. at 298. This information came from annual reports of Friends of the Court and from a questionnaire. Unfortunately, Chambers does not describe this questionnaire in detail.

29 Id. at 90. Chambers also reported that a fourth variable-the 1970 unemployment rate-was statistically significant. Id. at 91 . For my criticism of his use of this variable, see

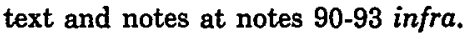

so All the counties were "self-starters" in cases involving welfare mothers. CHambERs at 94. See text and note at note 95 infra.

31 Chambers at 90.

32 Id. at 91 .

33 Id. For the population variable, Chambers uses the $\log _{10}$ of population. Id. at $91 \mathrm{n} .8$.

s4 Id. at 90-91. 
warnings collected little, if any, more than counties that jailed almost no one."ss Although he is less explicit on the point, it also appears that, after controlling for other factors, counties that were self-starting but had a low jailing rate collected little, if any, more than counties that were not self-starting. ${ }^{36}$ On average, counties that were both self-starting and had a high jailing rate collected $25 \%$ more of the support due than the other counties. ${ }^{37}$

Using these three factors, Chambers was able to explain about $60 \%$ of the variance in payment rates. ${ }^{38}$ No other independent variable was shown to be a powerful factor. ${ }^{39}$

The second issue he addresses-the differences in payment patterns for different types of fathers and the effects of different enforcement techniques on the various groups-involved the more intensive study of two counties. ${ }^{40}$ One was Genesee, an urban county, whose Friend of the Court used aggressive enforcement practices that involved the comparatively frequent use of jail.t1 The second was Washtenaw, a county containing both urban and rural areas, which devoted much less staff time to enforcement and rarely used jail sentences as a sanction for nonpayment. ${ }^{.2}$

Chambers collected detailed and extensive information for more than four hundred divorce cases for each of these two counties. ${ }^{43}$ The data came from payment records, which showed the father's payment history over the life of the case; enforcement logs, which described any enforcement efforts made; and a general file, which contained, among other things, information gathered at the time of divorce about the date and length of marriage, each

ss Id. at 91 (footnote omitted).

so "Under a self-starting enforcement system, a larger portion of men who falter are told to 'pay up.' The high rate of jailing seems to add, 'and we really mean it.' Neither message has potency without the other." Id. at 94 .

37 Id. at 93.

ss Id. at 91 .

39 Id. at 90 . For my criticism of Chamber's use of the 1970 unemployment rate, a variable he describes as statistically significant, see text and notes at notes 90-93 infra.

10 Macomb County also was given close study, Chambers at 18 , but Chambers relies primarily on information gathered about Genesee and Washtenaw Counties.

41 Id. at 17.

42 Id. at 18.

4s Id. at 285-97. The samples from the two counties were drawn from different years. For Genesee County, Chambers's sample was of divorce cases "that had an active support order for at least eighteen months, at least one day of which was in 1969 or 1970." Id. at 286. For Washtenaw County, the sample was from all divorce orders outstanding for at least 18 months, one of which was January 1972. Id. at 295. Four-hundred-twenty "usable cases" were developed for Washtenaw, id., and 411 were developed for Genesee, id. at 285. 
spouse's age, employment status, occupation, income, religion, and number and ages of the children. ${ }^{44}$ Using this information, Chambers, with the help of computer programs that aid in statistical analysis, ${ }^{45}$ explored the relation to payment of various background factors and events following the divorce, and also examined the relative effectiveness of the different enforcement techniques used by the two counties. ${ }^{46}$

When the data on fathers in Genesee County were placed into specific groups based on occupation, age, or length of marriage, Chambers found there were statistically significant differences in the payment patterns among various groups. Men in white-collar occupations, skilled blue-collar jobs, and unskilled autoworkers, for example, had better payment records than unskilled nonautoworkers; ${ }^{47}$ high earners paid better than low earners; ${ }^{48}$ men in their thirties at the time of divorce paid better, particularly when compared with men who were under twenty-five; ${ }^{49}$ and fathers whose children received AFDC paid considerably less than those whose children were not on welfare. ${ }^{60}$

Chambers suggests that the range of variation among groups of men, although statistically significant, was rather small. He reports that in Genesee County, for example, for the groups of thirty or more men with a common characteristic, no group paid an average below $62 \%$ of the amount due, nor more than $86 \%$ of the amount due..$^{51}$ In any event, the information available about individual fathers at the time of the divorce decree did not permit accurate predictions of how well a particular individual would pay. ${ }^{52}$

4 Id. at $290-91$.

4 Id. at 284.

48 Id. at 105-62.

47 Id. at 109.

48 Id.

49 Id. Whites paid at a slightly higher rate than blacks, but Chambers says the difference was statistically insignificant. That also was the conclusion for varying payment rates among members of different religions. Id.

so Id. at 133.

s1 Id. at 109.

s2 "The differences [among groups] here are so slight that they give almost no guidance about what payments to expect from a particular individual." Id. Chambers also discusses the effects of background on payment rates:

When we undertook a series of multiple classification analyses with all the factors ascertainable at divorce, sifting out those that retained a capacity to separate the higherfrom lower-paying groups, we found that we could now account for around 32 percent of the variation in payments. . . . The strongest factor was the attendance of the man at the predivorce interview. The length of the marriage to separation, the father's occupation, the year of the final order, the mother's age at the first child's birth, the num- 
Chambers's most striking finding came from his comparison of the payment rates of groups in Washtenaw, the lax county, with comparable groups in Genesee, the county more willing to jail fathers. He found that strict enforcement can result in greater collection from all groups. There were no identifiable groups of any substantial size that

paid at as high a rate in Washtenaw as their counterparts did in Genesee. ... .

.. . Just as the Genesee sample as a whole paid about 20 percentage points more than the Washtenaw sample of all that was ordered, so both the poorer- and better-paying subgroups within Genesee typically paid around 16 to 24 percentage points more than their counterparts in Washtenaw. ${ }^{\text {s3 }}$

Furthermore, Genesee was more effective in collecting from groups that generally paid least well. The county was able to collect a substantially higher percentage than Washtenaw from the three groups of fathers that had poor payment records: those whose wives had complained at the divorce that their husbands had provided inadequate support during marriage; those whose wives had asserted at divorce that their husbands had problems with alcohol; and those who were unemployed at the time of divorce. ${ }^{54}$ Chambers also found that Genesee's stricter enforcement could largely overcome any disincentive to pay stemming from the wife's remarriage. ${ }^{.5}$ The results of his data on the effects of aggressive enforcement led him to conclude "both that there are few identifiable groups so self-motivated toward payment that they pay as well as they are able without threat and, conversely, that there are few groups so unable to pay that the threat of jail does not produce substantial additional payments."

Significantly, Chambers found that Washtenaw's comparative

ber of children and the age of the father at divorce then followed ....

Id. at 115 .

s3 Id. at 118 .

st. at 119-20.

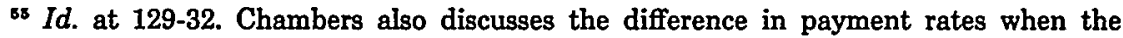
mothers are employed. Id. at 137-38. He describes the effect as "minimal," both in Genesee and Washtenaw Counties, a result that "suggests that in general employment by women is not a disincentive that strong enforcement is required to overcome but rather that it is simply not a disincentive at all." Id. at 138 . He advances some reasons why a father might consider that paying a working mother is more pleasing than paying one who has remarried or who is on welfare. $I d$.

Id. at 118-19. 
lack of success was not due to a failure to contact the fathers. In fact, Washtenaw sent out many more warning letters than Genesee. ${ }^{57}$ In comparing fathers who received warning letters, however, he discovered that, for every income group, Genesee men paid substantially better than Washtenaw men and also were subjected to fewer enforcement efforts. ${ }^{58}$

The explanation for the different effects of warning letters, Chambers found, is the different enforcement policy of the two counties. "In Genesee, it is simply far more frequently the case (though by no means always) that a warning letter that is ignored leads in fact to a warrant and perhaps an arrest, just as each letter threatens." Given that Washtenaw does not follow up warnings with forceful action, he found it "no surprise (though discouraging)" that there is this disparity. ${ }^{\circ 0} \mathrm{He}$ concluded: "Although this finding that Genesee's pressures produce responses from nearly all groups is a valuable finding, it still leaves hidden the reason for especially low payments by some men in each county."

Chambers also examined the characteristics of the men who were jailed in Genesee and compared them with the divorced men in that county who were not jailed. ${ }^{62} \mathrm{He}$ found that the jailed group contained a larger proportion of men who were unskilled blue-collar workers not in the auto industry, ${ }^{63}$ whose wives received welfare benefits, who had apparent alcohol problems, criminal records for other offenses, and high court orders in relation to their earnings, and men who failed to attend their predivorce interview. ${ }^{64} \mathrm{He}$ also found that, although most of both the jailed and general sample were white, a greater proportion of blacks were

${ }^{87}$ Id. at 158.

ss Id. at 159.

so Id.

so Id. at 162.

- Id. Chambers apparently never did determine the reason.

${ }^{62}$ Id. at 201-15. For this purpose, Chambers relied on two samples. First, he used the previously drawn random sample of some 400 Genesee fathers, of whom about $15 \%$ had been jailed. Id. at 201; see note 66 infra. Second, he was able to get background information from 191 of the men sentenced to jail during the same period. This second group constituted about $80 \%$ of the total sentenced to jail during this period. CHAmBers at 201 .

63 Chambers found that a substantial majority of those jailed were blue-collar workers. Chambers at 201-02. Compared with those in the random sample, twice as great a percentage of jailed men were unskilled blue-collar workers not working in the auto industry. Id. at 202. Those fathers who were auto workers paid at a considerably better rate. See id. at 338 , Table 9A.

Id. at 202. 
jailed. ${ }^{65}$

Chambers refined his analysis to compare the characteristics of jailed men with only those men who were twenty-six weeks or more in arrears by the end of any calendar year. ${ }^{66}$ For men with various characteristics, such as race and occupation, he computed the proportion that was jailed. He found that "neither unskilled blue-collar workers nor fathers of children receiving welfare are overjailed in relation to their frequency of falling into arrears." $\mathrm{He}$ did find that a higher-than-average percentage of certain groups go to jail: blacks, ${ }^{68}$ men with high payment orders in relation to their earnings, men with alcohol problems, and men with criminal records. He found that managers, professionals, and men with low payment orders in relation to their earnings were underrepresented. ${ }^{69}$

Chambers also was interested in examining the payment records of jailed men after their release from custody. To explore the specific-deterrence effects of jail, he traced the subsequent payment records of men jailed in Genesee and Macomb Counties. ${ }^{70}$ At

65 Id. See note 68 infra.

88 Chambers at 202-03. The figures and tables Chambers uses to present this information are disturbingly inconsistent and confusing. The text reports that of the random sample of 410 men, 233 were 26 weeks or more in arrears at the end of some calendar year. Id. at 203. Figure 9.1, however, which is presented as support for this statement, indicates that 231 men accumulated such arrearages. Id. at 204. The text states that 55 of the 233 men who were 26 weeks in arrears at the end of a calendar year went to jail. Figure 9.1, however, indicates that 60 men went to jail. Id. There also are inconsistencies in the reports of the racial composition of the sample. Table 7A indicates that of the 409 men in the sample, 318 were white, 46 were black, and 45 fell into the category of "missing data." Id. at 324. Table $9 \mathrm{~A}$ indicates that the sample contained 410 men, of whom 319 were white, 46 were black, 1 was "other," and 44 were "missing data." Id. at 338. Table 9B, based on the same sample, shows that there were 411 men, of whom 359 were white, 50 were black, and 1 was "other." Id. at 339. Not only are the numbers inconsistent, but they do not always add up to the stated totals. See, e.g., id. at 339, Table 9B ("Race").

67 Id. at 205.

(8) Although concerned that the jailing process might involve intentional discrimination on the basis of race, Chambers concluded that the evidence was too slim to justify such a finding. Id. at 206. One reason for this uncertainty is that blacks were underrepresented among those jailed more than once, $i d$. at 215 , and on average served shorter terms than whites, $i d$. at 206.

${ }^{82}$ Id. at 205. Chambers relies on these findings to suggest the possibility of arbitrary or discriminatory use of the jail sanction. Id. at 249. See text and notes at notes 130-132 infra.

70 Chambers gathered this data to determine the effects of the length of jail term on payments. Genesee and Macomb Counties both used jail frequently to enforce support, Chambers at 18, but in Genesee the conditional jail sentences imposed and the days actually served in jail typically were much longer than those in Macomb, id. at 192-93. In Genesee, for example, $63 \%$ of the men had 12-month conditional sentences, while in Macomb only $8 \%$ had sentences of this length; a majority were sentenced to 90 days or less. Id. at 336 . In 
the time they were jailed, those men typically were not meeting their payment obligations and also were substantially in arrears. ${ }^{71}$ Most of the jailed men eventually "bought" their way out of jail by a lump-sum payment, some sort of wage assignment, or both, although some men served the full term. ${ }^{72}$ To determine the effect of jail on payments, Chambers constructed a "combined payment index" that included both lump-sum and week-by-week payments following sentencing. In comparison to payments following warning letters, he found a substantial improvement in the average payment record for the jailed men for the period from the time of their release to the end of the next calendar year. ${ }^{73}$ Specifically, he found that jailed men as a group paid about half of what was due in Genesee County and nearly two-thirds in Macomb. ${ }^{74}$ This is in contrast to men who received only warning letters, only $10 \%$ of whom made both lump-sum and weekly payments. ${ }^{75}$

Chambers's study of Michigan support enforcement suggests four main conclusions. First, warnings alone do not appear to change conduct unless real sanctions are a possibility. Second, a credible threat of jail improves the payment record of every identifiable group of men-whether classified by age, type of employment, race, income, or events following divorce. Third, of the men who were jailed, nearly all of whom had poor payment records before jail, "a substantial number with prior erratic payments [began] to pay." Fourth, despite the costs of aggressive enforcement, "the gains in dollars are almost certainly far greater than the dollar costs."77 While Chambers is troubled by the policy implications

Genesee the median number of days actually spent in jail was 52, while in Macomb it was 6 . Id. at 337 . The mean days spent in jail were 99 days and 34 days, respectively. Id. Chambers is critical of the long terms imposed in Genesee. By comparing the collection results in Genesee and Macomb Counties, he mounts a persuasive argument that the length of terms in Genesee is longer than that necessary to secure either specific or general deterrence. Id. at 236-40.

71 Unfortunately, Chambers reports little information about the prior payment histories of the jailed men. He suggests that almost all were not currently paying, $i d$. at 217 , and that $80 \%$ of those jailed in 1969-70 had an arrearage of 26 weeks or more when jailed, id. at 203. For the jailed men who were in the Genesee Random Sample, it appears that only 5 of the 60 had accumulated an arrearage of less than 26 weeks. Id. at 203 n.2.

${ }^{72}$ Id. at $218-20$.

73 Id. at 231 .

74 Id.

25 Id.

78 Id. at 216.

${ }^{77}$ Id. at 101. Chambers makes a "generous" estimate that in Genesee County the "costs of the arresting, jailing, and self-starting policy in 1974 might have been as high as $\$ 400,000$." Id. at $101 \&$ n.17. He estimates that the returns attributable to the enforcement 
of these findings and by his inability to explain why some men will not pay or to predict in advance who they are, his study clearly indicates that self-starting jailing policies have substantial generaland specific-deterrence effects.

\section{II}

Chambers evidently began his study with a particular question in mind: does jail have an effect on collection rates? Fairly read, his study supports the notion that at least in some circumstances it does have an effect. Although his empirical findings are an important contribution, his presentation of them makes a serious probing of his methods and findings unnecessarily difficult. He is a fine writer who studiously avoids professional jargon. In this sense his book is unusually accessible. For a long, scholarly work that reports the results of a seven-year research project, however, the book does surprisingly little to relate its findings to prior research ${ }^{78}$ or to assist the reader in understanding exactly what Chambers did and why he did it. ${ }^{29}$

Much of the problem flows from Chambers's failure to develop, much less test, any coherent behavioral theory to explain why collection rates vary among counties and why some fathers

policy were nearly $\$ 3.5$ million, one-fifth of the total amount collected. Id. at 101 .

7 There is a voluminous literature on deterrence theory. See, e.g., sources cited $i d$. at 361-62. Apart from suggesting why his own results, which demonstrate the power of jail as a deterrent for failure to make support payments, should not be generalized, id. at 103, Chambers does not attempt to relate his work to other theoretical or empirical work on deterrence. He does contrast his study with that of Eckhardt, id. at 75-77,97-99, 112, but he does little to relate his work to other child-support research. J. CASSETTY, supra note 3, for example, is listed in the selected bibliography, ChamBErs at 359 , but it is otherwise unmentioned either in text or notes, even though Cassetty's analysis is relevant to Chambers's work and is based in part on data originally collected by the Survey Research Center at the University of Michigan.

Chambers also makes little effort to guide the reader to the considerable literature on debt collection and enforcement such as Comment, Debt Collection Practices: The Need for Comprehensive Legislation, 15 DuQ. L. REv. 97 (1976), and Note, Imprisonment for Debt: In the Military Tradition, 80 Yale L.J. 1679 (1971). In one footnote, for example, he cites P. Rock, Making People Pay (1973), but only for background on the use of jail for English debtors in the eighteenth century. Chamarss at 244 n.3.

70 Chambers's research associate, Terry K. Adams, did write a 20-page methodological appendix that describes the various data sets on which the research was based, the sampling techniques, and reservations about whether samples were representative. CHAMBERs at 283303. In addition, there are footnotes at the back of the book, some of which discuss technical details of the research methods. See, e.g., id. at $348 \mathrm{n} .18,350 \mathrm{nn} .8-9$. Nevertheless, the book does not provide a comprehensive and systematic account of the research procedures, all the variables tested, and the results. 
pay while others do not. Instead of developing and testing a theory, his approach was to collect data on scores of variables, use statistical techniques to explore the significance of these variables, report the variables that appear statistically significant, and then speculate about the meaning of the results. ${ }^{80}$

Chambers did not engage in a mere fishing expedition. The variables he tested were ones he believed were related in some way to "factors that might explain differences in collections." It also is clear that he thought that a father's ability and willingness to pay were important. ${ }^{\mathbf{2}}$ Nevertheless, Chambers neither formulated a theory in advance, to be tested against his data, nor did he use his statistical explorations to create a theory that might offer a causal explanation for his results at some level of generality. ${ }^{83} \mathrm{In}$ stead, he often offers hunches to explain the data. ${ }^{84}$ Many of these hunches are shrewd and plausible. Yet these largely anecdotal explanations of what the data mean are far less helpful than the explicit formulation of a theory, followed by an attempt to test that theory against the data.

Theory is important for several reasons. First, it is essential

so See Part I supra.

81 Chambers at 83.

${ }^{82}$ See id. at 83-90, 106-08.

${ }_{83}$ There are two approaches to the generation and application of theories. One is to work deductively, "from the top down." Here, one formulates an explicit theory in advance and then collects data that is used to test the theory. An alternative approach is to work inductively, "from the bottom up." Here, the researcher explores the empirical relationships found in data and from these explorations formulates a theory, which then is tested on a different set of data. A theory generated by such a "fishing expedition" cannot be tested on the data used to generate it. See Fisher, Multiple Regression in Legal Proceedings, 80 CoLUM. L. REv. 702, 715 (1980):

[W] hen faced with . . . a regression study, one should find out how the expert decided on the variables he included and how many different combinations of variables and models he tried before settling on the one that is being presented. If the basic model was tried relatively early and variations were then tried simply to see if anything else seemed to matter, the study may be sound. If, however, the basic model being presented is the end result of vast amounts of computer work, particularly mindless and mechanical computer work, then one may have a legitimate point of attack.

s4 One example is Chambers's analysis of data showing that unarrested men in Washtenaw County are subject to more frequent and more intense collection efforts than are unarrested men in Genesee. This contrasts with Genesee's higher collection rate. Chambers at 158. The two counties used similar techniques; both employed warning letters with substantially the same wording. Id. at 159. It is Chambers's "strong suspicion" that men in Genesee fear the enforcement letters more because of the county's jailing policy. Id. He cautions that this variable may not fully explain the results, and he offers a list of other possible explanations: "It could be that Washtenaw's enforcement efforts are ill-timed or in some other way, apart from the fate that befalls nonpayers, fail to carry the moral authority that Genesee's do, or that they lack some guilt-evoking quality that Genesee's have." Id. 
for exploring the causal relationships between variables. Looking at correlations that simply show that certain facts are associated with other facts is not illuminating. Social science searches for explanations. A theory can explain why two variables are associated. It is true that several theories may be consistent with the facts, and that no theory ever can be proved unquestionably correct by means of empirical research. For social science to be more than descriptive, however, empirical work should be related to theories that can be formally tested.

Second, theory contributes to subsequent research. The explicit formulation of theory facilitates the research of others, who might try to extend, criticize, or discuss the implications and limitations of the theory.

Third, without theory, it is difficult to evaluate a researcher's choice of variables or mathematical formulations used for statistical analysis. Indeed, without some implicit, if vague, theories, how does one decide what data to gather? In comparing payment rates of counties, for example, does one gather data on the average educational level of fathers? Or does one consider the patterns of church attendance for fathers, or how many fathers have red hair? If enough variables are tested statistically, the odds are that simply as a matter of chance one will turn up some variables that will appear statistically significant. ${ }^{\mathrm{Bs}}$

Because of the absence of any well-formulated theory, it is difficult to evaluate how Chambers chose variables to test, and to determine why he used particular mathematical formulations. The appendix suggests that, in comparing the payment rates of different groups of fathers, he gathered data on scores of variables. ${ }^{86}$ In analyzing the collection rates of the Michigan counties he tested some forty independent variables for their statistical significance. ${ }^{\mathbf{8 7}}$ The book does not describe exactly what these variables were, however, ${ }^{88}$ or why Chambers thought they were related to ability

ss See Fisher, supra note 83, at 715: "[A] study that casts about for a good-looking relationship by trying all sorts of possibilities is very likely to come up with relationships where none exist."

8s The Genesee Random Analysis Dataset, which "was used as the primary source for analyzing the overall payment performances of fathers . ... and the characteristics of divorced families," contained 327 variables. CHAmBers at 291.

${ }^{87}$ Id. at 321 , Table $6 \mathrm{H}$. The appendix states that " $[t]$ he final dataset had 240 variables for each of the 28 counties." Id. at 299.

s8 The appendix does say that lists of the variables can be obtained from the author. $I d$. at 285,321 . 
or willingness to pay-the two vague notions that he offers to explain why some fathers pay and others do not. Instead, Chambers reports only that these unspecified variables were statistically of little significance after controlling for the variables reported earlier. ${ }^{89}$

For those four variables in the twenty-eight-county study that Chambers does describe as statistically significant, ${ }^{90}$ it is useful to ask what justification exists for their inclusion based on a behavioral theory. For one variable-the 1970 unemployment ratethere seems no justification. In five of the six regression equations reported in the appendix, he has included the 1970 unemployment rate as an independent variable. ${ }^{91} \mathrm{He}$ reveals no theory to justify the use of this "lagged" (noncontemporaneous) variable, and considering that the more nearly contemporaneous 1974-75 unemployment rate apparently yielded statistically insignificant results, ${ }^{92}$ the use of the 1970 rate seems entirely unwarranted. ${ }^{93}$ There also are unanswered questions about the jailing rate variable $^{94}$ and the self-starting variable. ${ }^{95}$

sa Id. at 90 .

90 The four variables are the "self-starting" enforcement system; the rate of jailing in relation to county population; the population of the county; and the county unemployment rate. Id. at 90-91. Chambers labels the first three variables as the "dominant factors"; together they explain more than $60 \%$ of the variation in payment rates among counties. $I d$. See text and notes at notes 29-33 supra.

91 Chambers at 321-23.

82 Id. at 91 (referring to 1974-75 unemployment figures).

9s Chambers apparently thought that the use of unemployment was appropriate because he expected that "[w] hen unemployment rates are higher, collections are lower." Id. Presumably this was based on a notion that there would be more fathers who lacked the ability to pay during times of high unemployment. This notion would suggest, of course, that the relevant variable would be the unemployment rate roughly contemporaneous with the collection rates that he was trying to explain. The 1974-75 unemployment rate proved not to be statistically significant. Despite this result, Chambers proceeded to use as variables the unemployment rates of prior years, and the 1970 unemployment rate turned out to have a statistically significant relationship to collections. In short, it appears that it was only by using this "lagged" unemployment variable that any statistically significant results could be generated. Although he discloses the anomaly, he nonetheless used the variable and the reader is simply told that the results are "surprising." Id.

84 For his 28-county study, it is clear that Chambers's primary concern was to determine whether differences in the jailing rate made any difference in the collection rate. For these purposes he used the jailing rate "during a recent period, typically calendar year 1974," as the independant variable, id. at 83, in determining its effect on the 1974 collection rate. Because of county record-keeping practices, the period for which tabulations were made was calendar year 1974 for some counties and "a different several-month or one-year period generally overlapping part of 1974" for others. Id. at 82 . He does not provide specific information about the extent of variation among these measurement periods, presumably because he concluded that all periods that were used satisfactorily approximated calendar 
It appears that a rather simple theory, based on deterrence and economic analysis, might further an understanding of his results. Such a theory might suggest that a father rationally calculates whether or not to pay by evaluating the advantages and disadvantages of alternative courses of action. A father's decision would depend upon his preferences, income, attitudes toward risk, and expectations about the consequences of different courses of action. ${ }^{98}$

By paying support, a father receives whatever satisfaction he derives from an increase in the standard of living and consumption

year 1974. If this assumption is correct, it is apparent that his implicit theory is that the current jailing rate is what affects current payments. Is it so clear, however, that the current rate is the best variable to capture the father's expectations about the consequences of the failure to pay? It certainly would be interesting to know how the results would be affected if the jailing rate of some prior year were used as the independent variable, on the theory that a father's present perception relates not to what is happening this year, but, instead, to what happened in the recent past.

os The meaning of the "self-starting" variable is not clear. Indeed the name is something of a misnomer. All the counties were self-starting for welfare cases, that is, the Friend of the Court did not await a complaint from a welfare mother before pursuing a nonpaying father. Id. at 94. The so-called "self-starting" counties did the same for both welfare and nonwelfare cases. Id. at $90,93-94$. Yet the counties that were self-starting for nonwelfare mothers collected more from welfare cases as well. Id. at 94 . In light of this it is difficult to understand exactly why the "self-starting" variable should be important. Could it be that the expectations of prosecution of a father whose children are receiving welfare are affected by what happens to fathers whose children are not on welfare? Chambers suggests that the self-starting variable is probably a proxy for "the attributes of an efficient and persistent organization." Id.

There is reason to question the use of a binary variable (self-starting/non-self-starting) like this, especially as a proxy, when other, more direct measures seem possible. The book reveals that Chambers attempted to obtain information from a questionnaire about other enforcement techniques used in the 28 counties. Id. at 298 . As noted earlier, see note 28 supra, he does not describe this questionnaire in detail. It appears he was able to obtain information on the frequency of orders to show cause, but could not obtain an accurate count of the frequency of the use of warning letters. With only 28 counties being considered, it is not clear why it was impractical to estimate actual staff time used in enforcement. It is unclear whether he chose to use the "self-starting" variable because it gave the best statistical results and alternative variables were statistically insignificant, or because he was unable to get sufficient information to construct alternative variables, or whether he was motivated by some combination of the two.

- At one place in the book, in a section entitled "A Commonsense Theory of Payments," Chambers suggests that "[t]he father will pay if he is able to pay and if the combined weight of factors favoring payment (love, fear, guilt, whatever) exceed for him the weight of the factors favoring nonpayment." Id. at 107. See id. at 106-08. It is unclear, however, how one would test this statement or generalize from it. Unlike economic theory, which is premised on an individual's rational evaluation of alternative courses of action, his statement is a descriptive tautology: if the father somehow feels more like paying than not paying, he will pay. Saying that men act out of "love, fear, guilt, whatever" does not provide a coherent and testable theory of individual conduct. 
level of the child and the custodial mother. Payment leaves the father with less disposable income, however, and therefore deprives him of the satisfaction he would have received from spending the same amount on other things. For some fathers, the satisfaction of paying support is greater than the satisfaction from the alternative uses of his money. Such fathers would pay child support voluntarily, and for them there is no need for an enforcement mechanism. Other fathers, however, will make no payments without some system of sanctions that makes them view the probable consequences of nonpayment as less attractive than the satisfaction they would get from spending their money in another fashion. By choosing not to pay, a father increases the amount of money available for his own consumption, but also eliminates any satisfaction he might derive from increasing the child's consumption level; he also incurs whatever risks and costs are imposed by the child support enforcement process.

This theory offers one explanation of why the counties in Michigan collected a far greater proportion of support than Eckhardt had found was the case in Wisconsin. ${ }^{97}$ In Wisconsin, enforcement is not self-starting. A mother is required to go to court, and she bears the expenses of doing so.98 The typical litigation costs will be substantial in proportion to the amounts that mothers can collect. Many mothers may not have the cash to pay a lawyer a retainer in advance. Moreover, given the risks involved and the small amount at stake, private attorneys probably are reluctant to represent women on a contingent-fee basis. ${ }^{99}$ Thus, a father who knows that he can impose substantial costs and delays on the mother $^{100}$ may predict that if he fails to pay support, she may not bring suit at all; and even if she does, she may well settle for far less than the arrearages. In the Michigan counties, by contrast, the state bears the costs involved in enforcing support.

The theory also provides a plausible explanation for Chambers's finding concerning the differences in payment rates among the twenty-eight counties. A father's expectations of what will happen to him if he fails to pay support can substantially influence the payment rates. These expectations depend on his estimate of the

s7 See id. at 75-78.

98 Id. at 95-96.

92 See generally Leff, Injury, Ignorance and Spite-The Dynamics of Coercive Collection, 80 YALE L.J. 1 (1970).

${ }^{100}$ See J. CASSETTY, supra note 3 , at 106. 
probability that his failure to pay will be detected and the consequences for him if it is. All three variables that Chambers found significant are consistent with this theory: the size of a county and whether it is self-starting will influence a father's perception of the risks that his failure to pay will be detected and pursued, and the jailing rate affects his perception of the possible consequences. The theory would also lead one to predict that letters from a Friend of the Court threatening jail will tend to have little effect on collection if the threat is not credible, because it is the father's expectations of the consequences of his failure to pay that affect payments. The finding that Genesee collected more than Washtenaw from all groups of fathers is explicable because stricter enforcement affects the perceived risks of nonpayment for all groups.

This theory also may provide a plausible explanation for some of the variation in payment records for different groups of men. Chambers found, for example, that fathers whose children receive welfare paid less well on average than those whose children did not. ${ }^{101}$ When the children are receiving AFDC, the father's support payment goes to reimburse the state and typically does not improve the child's economic well-being. Because the child's standard of living is unaffected by a father's payment, paying is not a source of satisfaction for the father. ${ }^{102}$

Finally, the theory suggests that some fathers might take ac-

${ }^{101}$ Chambers at 136. In the 28-county survey, Chambers found that the average portion collected in welfare cases was about $25 \%$ less than it was for nonwelfare cases, and that in 24 of the 28 counties the average portion collected from welfare cases was even lower. Id. In Genesee County, where he had more detailed records on 51 cases, he found that by using multiple classification analysis the "beta" (roughly, the partial-correlation coefficient) of a welfare variable was reduced from, 27 to .13 by introducing six other variables, such as length of marriage and number of children. Id. at $353 \mathrm{n} .16$. He states: "To be sure, the aftercontrols difference [in collection rates between welfare and nonwelfare cases] does remain sufficiently large to be statistically significant $(p<.01$ ), but the difference is slight enough now for one to marvel at the closeness of the groups rather than to bemoan the distance between them." Id. at 135. It does appear that Genesee's strict enforcement system "is successful in keeping most men whose wives receive welfare from giving expression to their reduced incentive to pay." Id. See id. at 134, Table 7.4; id. at 333, Table 70.

${ }^{102}$ Apart from welfare cases, it would be interesting to explore how payment rates vary by income. Chambers had no current-income data for the Genesee Random Sample of men over the life of their payment records. Instead he had information about occupation and income at the time of the predivorce interview. Id. at 291. He found that payment rates in Genesee varied significantly by the father's occupation. Id. at 116, Table 7.1.

Economic theory suggests that, in a state with strict enforcement, mean payment rates will increase as income goes up because child support as a proportion of income declines, and because the opportunity cost in lost income of going to jail is higher. The perception of the stigma associated with jail may also vary with income. 
tions to reduce the probability of detection of nonpayment. The most obvious way for them to do this is to leave the county. Chambers reports that a significant fraction of fathers did move out of Genesee County, and that collection from these men was poor. ${ }^{103}$ This suggests that fathers might perceive that the risk of punishment for nonpayment is substantially less when one has left town. ${ }^{104}$

Economic theory points to an explanation for another phenomenon as well. Chambers suggests that once a father gets out of the habit of paying, it takes considerable effort to make him change his ways. ${ }^{105}$ People usually lower consumption more slowly when income falls than they increase consumption when income rises. By not paying child support, a father can increase his disposable income. Over a period of time his consumption patterns will accommodate to this higher level of income. Resuming support payments would lower the father's consumption, so consumption theory would indicate that fathers would resist this effect and thus try to avoid paying.

I do not want to convey the impression that Chambers overlooked the connections suggested by this theory. In reporting his findings and his hunches about causal links he suggests many of them. He believes that the threat of jail did cause some men to leave the state, for example, ${ }^{108}$ and he notes that a father's support payments do not directly benefit a child on welfare. ${ }^{107} \mathrm{He}$ never ties these observations together, however, either before or after reporting his results; nor does he suggest a coherent theory on which other researchers can build.

The theory outlined here is simple; it has not been specified

${ }^{103}$ Id. at 124-26, 232 n.11.

104 The Genesee data suggest that one consequence of aggressive enforcement may be to drive a significant number of fathers out of a county. Unfortunately, Chambers reports no data about how emigration rates varied among the counties. It is possible that the 28-county analysis overstates the effectiveness of jail if many fathers left a county with strict enforcement. On the other hand, this cross-county analysis might understate the effectiveness of jail if counties contained differing proportions of cases in which a father knew he would not be pursued because his file was inactive. A generally high jailing rate alone is not what influences a father; more significant is his perception of the risk that he may be subjected to this sanction if he fails to pay. For a father who knows that his file is inactive, my theory would suggest that there is no reason to think that a higher jailing rate necessarily will influence his payment rate. After all, the actual probability of his being sent to jail may be zero even though the county's overall jail rate is high.

105 Chambers at 101.

108 Id. at 126-27.

107 Id. at 133. 
and formally tested against the data Chambers collected. The purpose of presenting it is to show how a simple theory can be used to organize and give some coherence to findings. Furthermore, a theory that is tested can then be used by researchers in other contexts to determine whether the results are similar.

\section{III}

Chambers found that using jail to enforce child support has useful general-deterrence effects and also may lead to higher payments from the men who are jailed. Nevertheless, he fervently argues against the use of jail. Although he raises a number of questions and presents a variety of arguments, none ultimately is persuasive.

To begin with, after asking "how heinous an act is willful nonsupport?,"108 Chambers suggests that jailing for nonsupport "should give us pause"109 for two reasons. He first questions the use of jail for the enforcement of a support obligation because "jailing for an arrearage in court-ordered support is indeed a form of jailing for debt."110 We do not jail for other forms of debt, so why use jail for nonsupport? The answer is that there are significant distinctions between jailing for debt and jailing for nonsupport, distinctions that he himself acknowledges. ${ }^{111}$ First, the failure to pay support may have more serious consequences than a commercial bad debt. In the support situation, the child and custodial parent suffer. A commercial bad debt may be considered a risk of doing business; a company often is able to spread the cost of baddebt losses among customers in the form of higher prices. By contrast, one may argue that a father's avoidable nonpayment should not be one of the acceptable risks of the failure of a marriage. Furthermore, when fathers do not pay support, the mother and child have no means of spreading the burden unless society makes up part of the loss in the form of higher welfare payments.

A second reason jail may be appropriate here but not in the enforcement of commercial debts is that the failure to pay support may be considered more blameworthy. As Chambers recognizes, the duty to support one's children might be seen as more funda-

108 Id. at 244.

109 Id.

110 Id.

111 See id. at 245: "In most respects the failure to pay child support seems vastly different from the failure to pay commercial debts." 
mental than the duty to pay one's telephone bill.112 The intentional failure to pay might be likened to tax evasion or willful passing of a check with insufficient funds, crimes considered serious enough to lead to jail. Even if the deterrent effects of jailing would lead to higher payments of commercial debts, the principle of just deserts-or what Professors Zimring and Hawkins have called "the retributive limit" of deterrence ${ }^{113}$ _might distinguish the two situations.

Chambers's second concern about jailing for nonsupport relates to the intrafamilial nature of the offense. He suggests that some fathers may not pay child support because of anger against their former wives, or as a consequence of emotional stress after divorce. Drawing an analogy to the frequent reduction from firstto second-degree murder convictions in the cases of husbands who kill their wives, he argues that the sanctions against fathers who fail to pay support should be similarly mitigated. In his view, jail is an inappropriate punishment for such "second-degree" failure to support. ${ }^{114}$

There are several grounds for rejecting the claim that the intrafamilial nature of the offense renders jailing inappropriate. One is that a crime committed in anger is still a crime; the punishment may be reduced, but anger does not provide a complete excuse from criminal sanctions unless a person lacks the mens rea to commit the offense. Husbands are sent to jail for second-degree murder; their sentences may be shortened, but they still are guilty. Therefore, the analogy demonstrates only that fathers who are guilty of "second-degree" nonsupport should be punished less severely than for "first-degree" nonsupport, not that they should be excused entirely.

112 See id. at 244-45.

113 F. Zimring \& G. Hawkins, Deteraence: The Legal Threat in Crime Control 50 (1973). The idea is straightforward: even if the punishment of $A$ has powerful deterrent effects on $B, C$, and $D$, by the principle of retribution or blame $A$ should not be punished more harshly than he deserves.

114 Chambers at 246. Chambers's study does not reveal how frequently the reason fathers do not pay is anger at their former wives. Absent a firm belief that this often is the reason, one hardly could claim on this ground that jailing for nonsupport should be prohibited in all cases. If justifiable anger were allowed as a defense in individual cases, it would present the extremely difficult task of evaluating the father's state of mind at the time he refused to pay, and of relating this state of mind to the former relationship of the spouses. Even if one thought that as a theoretical matter an excuse based on anger was appropriate in some cases (something I do not believe, for reasons stated in text), one nevertheless could object to a defense that would be raised frequently, would require time-consuming and difficult evaluations, and would rarely be a justifiable excuse. 
Furthermore, an intrafamilial killing may involve a single act done impulsively, in a moment of uncontrolled anger. The failure to pay child support, by contrast, typically occurs over an extended period of time-months or even years-before a man is prosecuted. This conduct is more akin to a spouse slowly poisoning his mate over a period of years than to a husband shooting his wife in the midst of a violent argument. One also wonders why anger toward the wife is an excuse for an act that directly harms the child. We surely would not absolve a father of the blame for child neglect if for six months he refused to prevent his child from starving on the ground that during the entire period he was extremely angry at his wife. In any event, it should be lack of deliberation, not the intrafamilial nature of the offense, that constitutes a mitigating factor. ${ }^{115}$ Furthermore, there is no basis for assuming that because the child's parents are now divorced, nonsupport ordinarily is unintentional.

The primary argument Chambers makes against the use of jail concerns the administration of the jailing process. Many more fathers fail to pay at some time than are ever jailed. ${ }^{116}$ As a consequence, there is a selection process that Chambers suggests necessarily creates "countless opportunities for abuses."117 He reports finding that, among those jailed in Genesee County, men with employment difficulties or with alcohol problems are overrepresented, while managers and professionals are underrepresented. ${ }^{118} \mathrm{He}$ suggests that many who are jailed are less blameworthy than those who are not, and that they remain in jail because of their poverty. $\mathrm{He}$ also asks whether, given the limits of human competence, discriminatory or unfair administration is inherent in the offense or whether any system using jail widely can be tolerably fair. ${ }^{118}$

To understand this argument, it is helpful to consider the peculiar nature of civil contempt. Courts often state that its purpose

125 Traditionally, certain offenses, such as rape, could not occur between a husband and wife, largely because of a hands-off attitude toward violence within the family. There is increasing pressure today to apply ordinary criminal-law protections to wives during marriage. It would be ironic if the "intrafamilial nature" of the offense here should be an excuse after the marriage ends.

116 Chambers reports that in Genesee County only about $25 \%$ of those who fell more than six months in arrears ever went to jail. Chambers at 203.

117 Id. at 248.

118 Id. at 202. He also reports that by some measures blacks and those with prior criminal records are also overrepresented, but he was unable to conclude there was any racial discrimination. See note 68 supra.

110 Chambers at 247. 
is coercive and remedial, rather than punitive, and that defendants "carry the keys of their prison in their own pockets"120 because they will be released once they comply with the court order. The problem in the support situation is determining a defendant's ability to comply with the court order. It is usually not difficult to decide whether a father willfully refused to pay child support when he had or could have had the money to pay. Chambers does not claim that the jailed men in Michigan had never willfully refused at some time when they could have paid. The problem arises when the defendant who could have paid at the time of his refusal now lacks the capacity to meet the court's present order, which may require current support payments and some amount to clear up the arrearages.

No man should be kept in jail for civil contempt if he is unable to comply with the court's order. ${ }^{121}$ The difficulty is that the court has the right to be coercive-to squeeze hard to get the man to pay up what he can-but there is no easy way for the court to know in advance what amount a father now can pay. The court does not know, and the father has no interest in confiding to the judge, just how much money he might be able to obtain from relatives, friends, or from his own resources. It may be inevitable that civil contempt involves a bargaining process ${ }^{122}$ over the conditions of release once the father is jailed; the state has an interest in collecting as much as possible, but it should not ask the impossible.

Chambers found that over half of the jailed men in fact did buy their way out of jail after sentencing. ${ }^{123}$ This suggests that most who have paid nothing can come up with something. Of those men who remain in jail, some may do so because they are stubborn - they could comply, but prefer not to pay, ${ }^{124}$ it is sensible to require them to serve the full term. Other men, however, may remain in jail because the conditions set for their release are too stringent. In essence, Chambers challenges the fairness of using a

${ }^{120}$ In re Nevitt, 117 F. 448, 461 (8th Cir. 1902); accord, Sword v. Sword, 399 Mich. 367, 383, 249 N.W.2d 88, 94 (1976). This reasoning often has been attacked as specious. See, e.g., R. Goldparb, The Contempt Powkr 58-59 (1963).

121 This appears to be the law today, see note 14 supra, even in Michigan, see Sword v. Sword, 399 Mich. 367, 379, 249 N.W.2d 88, 92 (1976), although Chambers does not acknowledge the point.

${ }^{122}$ Chambers describes the bargaining process that occurs in Genesee after the father is in jail. He notes that "[t]he closer it came to the end of the man's term, the smaller an amount the officer would typically accept." ChamBers at 192.

123 Id. at 191-92.

124 Id. at 192. 
coercive process involving jail that creates risks that some men may be punished rather than simply coerced while other men who may be equally blameworthy do not go to jail at all or serve only short terms. His concern is that the selection process will necessarily be inaccurate, and that the relation between the punishment imposed and the fault will be arbitrary.

In evaluating this argument, it is useful to distinguish and consider three separate issues. The first and perhaps crucial question is whether the men who are jailed deserve to be there. ${ }^{125}$ If the answer is yes, the second issue is whether it should matter that only some of the guilty are jailed, and that the punishment may not be proportional to the offense. The third question is whether the process of jailing for civil contempt is unfair because a defendant lacks the procedural safeguards in court that are ordinarily available to a criminal defendant.

Deciding whether the jailed men are sufficiently blameworthy to be incarcerated or whether they are impermissibly jailed for poverty depends upon how one characterizes the offense. If one decides that the men are jailed not because they are unable to pay now, but because in the past they willfully defied a court's order to pay when they had the capacity to do so, the practice seems much less like jailing for debt than jailing for civil contempt. Given the

${ }^{125}$ One fact worth noting in considering the issue of blameworthiness is that most people who are jailed have made little or no effort to cooperate with the Friend of the Court in setting up a payment schedule or in making some other arrangement. Chambers quotes an officer of a Friend of the Court as saying: "No one is ever jailed . . . for not paying. They are jailed for not cooperating.' "Id. at 180.

I am unimpressed by Chambers's argument that the process in Genesee County was unfair because the jailed men may represent only one-fourth of those who were even more than six months in arrears. Id. at 203. Anecdotal evidence from the book suggests that the men who are jailed typically are much farther behind in payments. It hardly seems arbitrary to jail those who have paid the smallest proportion over time. Unfortunately, Chambers does not indicate whether the men who go to jail are on average much farther in arrears than those who do not.

The choice of the 26-week measure seems inappropriate because it may combine men with very different overall payment records. The 26 -week arrearage did not have to be accumulated in a single year or a single 12 -month period-it could be accumulated over a number of years. Id. at $354 \mathrm{n} .1$. It therefore could include both a man who paid in full for 46 weeks a year during the five years following his divorce (an overall payment index of .88 ), and a second man who had been divorced six months and had paid nothing (a payment index of .00). Both would be 26 weeks in arrears, but one might expect enforcement officers and judges to treat these two men very differently. Indeed, Chambers apparently discovered in his multiple-classification analysis that jailing was "more likely to befall . . . those who built the twenty-six weeks of arrearages in the early years of their order." Id. at 205-06. He writes that he tried several different measures to create a pool of jailed men, id. at 203, but he reports the results only for the 26-week measure. 
long periods for which many of the jailed men were in arrears, the inference that they could have been making some payments is plausible. Under this view, Chambers's claim that there should be "a defense for the unemployed as well as for persons with incomes below the single-individual Lower Standard Budget level"128 is unwarranted. Instead, a defense might be that a father's income was extremely low over an extended period of time; such a defense presumably would be grounds for a formal modification of the amount of support he must pay.

The real question here is whether men who willfully fail to pay support should be held responsible. Obviously, someone with no income over an extended period may never have had the capacity to pay and therefore should not be jailed. Anyone who intentionally refuses to pay support when he has the ability to do so, however, is sufficiently blameworthy to justify a jailing sanction. One may note that it is not a defense for tax fraud that one lacks money at the time of the prosecution. In tax enforcement, as here, the relevant inquiry should be whether there was a willful failure to pay when the defendant had the money. Chambers provides no evidence that any significant number of jailed men were not blameworthy in this sense.

The second troubling issue is that even if the men who are jailed are blameworthy, one may wonder whether it is fair to jail them if other men, who also at one time willfully refused to pay, can avoid jail simply by paying up. This risk of unequal treatment is implicit in the nature of a civil contempt action, for any man who pays up can avoid jail. Or, to put it more precisely, some men may spend time in jail because they are unable to comply with the conditions set for their release. Are these men any more blameworthy than those who were able to buy their way out of jail? Of the fathers who have intentionally failed to pay, is it fair to jail only those who are too proud to pay or who lack the resources at the time of sentencing to offer some acceptable arrangement? For proud men, the answer is easy-they must pay. For the others, however, it can be argued that the sanction is impermissibly underinclusive because men who pay up are not punished.

Although troubling, underinclusiveness is an insufficient reason for abandoning the use of jail. Fathers who willfully refuse to pay and then pay up only when sentenced to jail are treated too

120 Id. at 249 . 
leniently, ${ }^{127}$ but they may be less blameworthy than those who never pay. The consequences for the families of those who are unable to pay at the time of the sentencing are more serious than for those who can pay. Both classes of men may be equally blameworthy in terms of creating the risk of harm, but the actual harm caused by an intentional refusal to pay is more serious when at the time of sentencing a father cannot pay up. In other contexts, furthermore, we consider the consequences of the blameworthy conduct in imposing legal sanctions: "attempts," for example, usually are punished less severely than completed crimes. ${ }^{128}$ I am disturbed that some men may remain in jail because the conditions set for their release turned out to be too high, but this problem can be reduced by short maximum terms - the data Chambers presents suggest that a term of sixty days suffices to secure the deterrent benefits of the civil contempt sanction. ${ }^{129}$

Chambers also is disturbed that few men with higher incomes are jailed. ${ }^{130} \mathrm{He}$ notes especially that unemployed fathers go to jail much more frequently than those with higher incomes. ${ }^{131} \mathrm{He}$ speculates that these disparities might occur "simply because some nonpayers are more easily found than others. It might also occur because some men who become deeply in arrears are more responsive than others to less drastic enforcement techniques."132 Given the nature of the offense, it is hardly surprising that few wealthy men go to jail. Higher-income men pay better along the way, and although Chambers never reports whether his data show that such men are more likely to pay up when they are seriously threatened with jail, they probably are more likely to do so. In any event, evidence that more lower-income men commit a certain sort of offense should not be a defense.

Another of Chambers's concerns is that a significant proportion of those who are in jail are men whose wives complained at the time of divorce that their husbands had some alcohol problem. "It is ironic that this group should bear so much of the brunt of

127 At a minimum, the state should require the delinquent father to pay interest if he has the ability to do so.

${ }^{128}$ Also, in tort law we impose damages on persons whose negligent or reckless conduct causes harm, without imposing any legal sanction on those whose conduct improperly creates a risk but causes no harm.

129 Chambers at 240.

1so Id. at 206.

131 Id. at 207.

132 Id. at 205. 
the enforcement system since there must be more doubts regarding its capacity to pay than there are about almost any other group of nonpaying men."1ss One wonders, however, whether it really is ironic in light of Chambers's own evidence that Genesee County, with strict enforcement, apparently collects a considerably higher percentage from such men than Washtenaw, with lax enforcement. This evidence suggests that such men often can pay, although they may be more reluctant than others to do so. Moreover, it should be recalled that for purposes of the criminal law generally, alcoholism is not a defense or an excuse. ${ }^{134}$

Chambers's third major concern is that defendants in civil contempt proceedings have insufficient procedural safeguards. ${ }^{\text {1ss }}$ $\mathrm{He}$ is rightly concerned that many men who are sent to jail are not represented by counsel in the proceedings. ${ }^{136}$ Counsel certainly

$13 s$ Id. at 250.

134 See generally W. LaFave \& A. ScotT, Handbook on Criminal Law 350 (1972).

1ss Chambers at 174-89.

${ }^{138}$ Chambers is highly critical of the Michigan Supreme Court's unanimous decision in Sword v. Sword, 399 Mich. 367, 249 N.W.2d 88 (1976), that in a civil contempt proceeding a father has no constitutional right to assigned counsel. The opinion emphasized that the purpose of civil contempt was remedial and coercive, not punitive, that "unlike in a criminal contempt, the defendant must be placed in a position of holding in hand "the keys to the jail," " $i d$. at 383,249 N.W.2d at 94, that the state had an important interest in "obtaining support for minor children," id., and that assigning counsel in all cases would increase costs and might involve delays, id. Although Sword can be read to allow imprisonment only for defiance of an order that the defendant is currently able to obey, see note 14 and text and note at note 121 supra, Chambers characterizes as "disingenuous rubbish" the notion that an attorney was not necessary because the father had the "keys to the jailhouse in his pocket." Chambers at 187. He says:

Judges never inquired whether men had cash on hand equal to the portion of the arrearage demanded as the price of release. Nor was any man released simply on saying that he promised to begin paying. The real rationale for the Michigan decision was probably that the justices knew that to provide lawyers would cost money and that county officials were already complaining about the costs of providing lawyers in other settings.

Id. He speculates that the underlying reason the state officials objected was not the cost but that,

at least in part, judges and staff knew that lawyers would force them to treat as individuals men whom they have been accustomed to treating as stereotypes and that locking people in jail is less easy when a person of respectability-the lawyer-starts proposing individual plans that sound reasonable. The staff members of the Friends of the Id. Court enjoy the power they have.

State courts elsewhere have required assigned counsel in civil contempt proceedings, emphasizing the potential loss of liberty for the defendant, and characterizing the proceedings as quasi criminal under Argersinger v. Hamlin, 407 U.S. 25 (1972) (counsel required for misdemeanors punished by imprisonment). See, e.g., Otton v. Zaborac, 525 P.2d 537, 538 (Alaska 1974); Tetro v. Tetro, 86 Wash. 2d 252, 254-55, 544 P.2d 17, 19-20 (1975). The 
should be made available, but the absence of counsel in itself does not render the sanction theoretically inappropriate. The same is true of other safeguards. ${ }^{132}$

The other arguments Chambers presents are much less compelling. One is based on the possible effects of jailing policy on children. ${ }^{138} \mathrm{He}$ acknowledges that a strict enforcement policy that includes jail may lead some fathers not only to pay but also to maintain contact with their children. ${ }^{139}$ Thus, the policy can have both economic and nonpecuniary benefits for some children. $\mathrm{He}$ is troubled, however, that a jailing policy may hurt some children by making them feel responsible for the jailing of their fathers. ${ }^{140} \mathrm{He}$ presents no evidence documenting the frequency or the degree of psychological harm suffered by children whose fathers are jailed. In any case, in considering the effects on children, it is certainly possible to imagine that some children are benefited by strict enforcement and others are hurt. A guess might be that because of the apparent degree of general deterrence, more children are helped than hurt. Chambers seems to consider the relative proportion unimportant, however, for he ends up with a rather startling assertion: "If there is a serious possibility of harm to any substantial number of children, a good case can be made that jailing should be avoided, even if many more children will be aided than will be hurt."141

This conclusion is based on an implicit distinction between action and inaction. Putting fathers in jail involves state action. Refusing to use the sanction to help collect support is inaction.

United States Supreme Court has not ruled on this issue.

${ }^{132}$ A jury trial should not be required in a civil contempt proceeding, particularly so long as the maximum conditional term is less than six months. Sword v. Sword, 399 Mich. 367,249 N.W.2d 88 (1976), held that a jury trial was not constitutionally required in civil contempt proceedings in Michigan. Under the authority of Duncan v. Louisiana, 391 U.S. 145 (1968), there is no federal constitutional right to jury trial for a misdemeanor punishable by jail terms of less than six months. The court in Sword indicated that although the Michigan civil-contempt statute permitted a conditional maximum period of incarceration of one year, "the defendant may free himself by complying with the order." 399 Mich. at 386,249 N.W.2d at 95 . For a defendant who lacks the ability to comply, that is not persuasive if he must serve six months or more. A jury should not be required, however, if the underlying offense permits imprisonment only if a defendant has been determined able to comply with the order. Moreover, the problem would be solved if the maximum sentence were reduced below the Duncan limit of six months; a criminal-contempt proceeding would not require a jury trial.

198 Chambers at 250-53.

138 Id. at 251.

140 Id. at 252.

${ }^{141}$ Id. 
Chambers apparently believes that somehow the state is responsible for the children harmed from a strict enforcement policy, but not responsible for the avoidable harm to children who are hurt by lax enforcement. This distinction seems extremely artificial in a context in which the law has defined the father's duty to support, a court has ordered the support, and the state is responsible for a mechanism for support enforcement. It is difficult to understand why the state should not be held responsible for the consequences of its failure to use jail as an enforcement technique. ${ }^{\mathbf{1 4 2}}$

In his last chapter, Chambers suggests that there may be some "less restrictive alternatives" to jail, ${ }^{143}$ and that as a consequence jailing may be unnecessary. He suggests a more frequent use of garnishment of wages and briefly sketches the possible creation of a national compulsory wage-assignment system. ${ }^{144}$ Although the evidence does suggest that garnishment works in many cases, it does not indicate that jail is an unnecessary additional sanction. The wages of many fathers, such as those who are self-employed, cannot be garnisheed. Chambers's argument does suggest that if there were mandatory withholding of child support payments it might be far less frequently necessary to resort to the sanction of jail. In any event, the idea of national compulsory wage assignment, although only briefly outlined in the book, certainly deserves serious consideration.

Chambers also proposes changing the underlying support obligations so that three years after a divorce a father no longer has a legal duty to make any such payments. He does not offer this as a serious proposal for 1981 -indeed, he describes it as part of a vision of what the world should be like in the year $2025 .^{145}$ There is a good reason for this. Given the relative income disparity between men and women today, it would be difficult to make a case that, without substantial increases in public support for single parents, absent fathers should be let off the hook.

${ }^{142}$ Alternatively, the argument can be put in terms of children's rights. Chambers in effect is arguing that all children should have a right not to be harmed by the consequences of the state's attempt to collect money from their fathers, even though the result would be that children would have no right to have child support collected on their behalf if jail were the only way to get it. Michigan's child support legislation, however, expressly establishes the right of a child to be supported. There is no right for children or others to avoid harm when culpable people are punished. Indeed, most punishments of culpable people hurt innocent people, and children may often be harmed when a culpable parent is punished.

143 Chambers at 253.

144 Id. at 258-61.

145 Id. at 279. 
Although Chambers expresses sympathy for the plight of a single woman and her children, he weighs their interests less heavily in his arguments than I would. If increased welfare payments will not provide adequate levels of support following divorce, then the consequence of a father's failure to pay is to impose increased economic burdens on a woman and her children. Many women may be able to make up this difference by entering the work force or working longer hours. This involves substantial sacrifices of their time. Moreover, given that working women as a group have substantially less income than working men, it hardly seems fair.

The ultimate question is who should bear the additional costs of two households, and what should be the distribution of burdens between the households. This is a serious and important question. None of Chambers's evidence, however, suggests that fathers are bearing too much of this burden at the present time. Indeed, commentators have suggested that even court-ordered child support levels (not the actual amounts paid, which are much less) are set much too low, ${ }^{148}$ and that the failure to adjust support for inflation makes this even more the case. ${ }^{147}$ In short, making fathers pay is a nasty but often necessary task.

\section{Conclusion}

Despite my disagreement with Chambers's policy conclusions, and some concern about his methodology and presentation, this book makes a substantial contribution that should refocus all subsequent discussion of child support enforcement. Its contribution might have been even greater had Chambers separated more clearly the presentation of his empirical research findings from his various arguments against the use of jail, and devoted more energy to relating his empirical research to earlier work and to the development of the theory. This might have been facilitated, for example, if he previously had published the results of the various phases of his empirical work in a series of journal articles that laid out in

146 See J. CASSETTY, supra note 3 , at $82,103,105,124-25$.

147 Chambers speculates that some fathers who are made to pay by the threat of jail in effect are taking money from their new families and redistributing it to their old families. Chambers at 133. He indicates that the new family may be poor as well, and that the distributional consequences of this shift are of doubtful fairness. This may well happen in some cases, but the issue posed is the scope of the appropriate support duty, not the sanction. The question is whether the father's remarriage and increased expenses in this new household should affect the amount of his support obligation. 
considerable detail his methods, variables, and findings. ${ }^{148}$ The book might then have drawn on that research, referred the more technically inclined reader to the previously published work, and devoted itself primarily to exploring in detail for a general audience the policy alternatives and dilemmas.

Chambers's decision not to proceed in this way is an entirely understandable one, however. He no doubt feared that his own empirical research (particularly if presented without arguments against jail) might be misused to justify jailing practices beyond anything found in Michigan today, and might be employed in an unthinking way to deprive disadvantaged people of their liberty.

In any event, Chambers resolved the tension between his research findings and his policy preferences in an entirely professional way. He had the imagination, patience, and perseverance to go through the time-consuming process required for original empirical research. He did not base his policy recommendations simply upon his own values and beliefs. Moreover, when the results of that research were not what he anticipated, and in fact conflicted with the policies he preferred, he nevertheless accurately reported his findings and then fashioned arguments against their clear, but to him unfortunate, implications for policy. Making Fathers Pay documents what for its author must have been an unhappy discovery: Bentham and Hobbes may be right that the systematic application of force, and the threat to use it, can change conduct for the better.

248 Only the results of the 28-county comparison were previously published. See Chambers, Men Who Know They Are Watched: Some Benefits and Costs of Jailing for Nonpayment of Support, 75 MrCH. L. REv. 900 (1977). 